\title{
Determination of Quality Standards for Management and Administrative Services in Science Teacher Training Programs ${ }^{1}$
}

\author{
DOI: 10.26466/opus. 893880
}

\author{
Adem Yilmaz ${ }^{*}$ - Seyit Aydin** \\ * Dr. Öğr. Üyesi, Kastamonu Üniversitesi, Eğitim Fakültesi, Kastamonu/Türkiye \\ E-Posta: yilmazadem@kastamonu.edu.tr \\ ORCID: 0000-0002-1424-8934 \\ ** Prof. Dr., Ankara Yıldııım Beyazıt Üniversitesi, Meslek Yüksekokulu, Ankara/Türkiye \\ E-Posta: seyitaydin@ybu.edu.tr \\ ORCID: $\underline{0000-0001-7880-9780}$
}

\begin{abstract}
A country's competitiveness and development efforts are determined by the qualified manpower it has trained. Reaching qualified manpower is possible with a good higher education. At this point, quality and competencies of higher education institutions come to the fore. In this direction, families are constantly researching for their children to have a good university education and take into account quality indicators to make a good choice. In this study, science teacher training programs, which are higher education programs, were examined in terms of quality standards for management and administrative services. A quality standard scale has been developed within the scope of the research. The survey method, which is one of the quantitative research methods, was used in the research process. While determining the research sample, criterion sampling and appropriate sampling types were preferred. 1352 people participated in the study voluntarily and willingly. As a data collection tool, a Likert-type scale with 7 factors and 58 items was used by the researchers. The data obtained within the scope of the research were analyzed using SPSS 20.0 and LISREL 9.2 package programs. As a result of the exploratory factor analysis of the developed scale, it was seen that the factor loads varied between .402 and .907 . The Kaiser-Meyer-Olkin value was determined to be .817. It was found that the total variance explained was $55.93 \%$ and Cronbach's Alpha value was .907. As a result of the confirmatory factor analysis, it was found that $X^{2} / D f$ value was $1.93, R M S E A$ value was .04, NNFI value was .95, SRMR value was .07 and AGFI value was .75. According to the results of the research, a valid and reliable scale was developed and it was determined that the stakeholder opinions (prospective teachers, teachers, faculty members) contributed to the quality standards at "a very significant" level.
\end{abstract}

Key Words: Science teacher education program, management and administrative services, quality standards, scale development

\footnotetext{
$1{ }^{*}$ Bu araştırma 18-22 Nisan 2018 tarihleri arasında Antalya'da düzenlenen $27^{\text {th }}$ International Conference on Educational Sciences (ICES UEBK) kongresinde sözlü (özet) bildiri olarak sunulmuş olup birinci yazarın doktora tezinden üretilmiştir.
} 


\section{Fen Bilgisi Öğretmen Yetiştirme Programlarında Yönetim ve İdari Hizmetlere Yönelik Kalite Standartlarının Belirlenmesi}

\section{Öz}

Bir ülkenin rekabet edebilme gücü ve kalkınma çabaları yetiştirmiş olduğu nitelikli insan gücü ile belirlenmektedir. Nitelikli insan gücü ise iyi bir yükseköğrenim ile mümkün olmaktadır. Bu noktada yükseköğrenim kurumlarının niteliği, kalitesi ve yetkinlikleri ön plana çıkmaktadır. Bu doğrultuda aileler, çocuklarının iyi bir üniversite eğitimi almaları için sürekli araştırma yapmakta ve iyi bir seçim yapmak için kalite göstergelerini dikkate almaktadır. Yapılan bu çalışmada, bir yükseköğretim programı olan fen bilgisi öğretmen yetiştirme programları yönetim ve idari hizmetlere yönelik kalite standartları açısından incelenmiştir. Araştırma kapsamında bir kalite standardı ölçeği geliştirilmiştir. Araştırma sürecinde nicel araştırma yöntemlerinden olan tarama yöntemi kullanılmıştır. Araştırma örneklemi belirlenirken ölçüt örnekleme ve uygun örnekleme türleri tercih edilmiştir. Araştırmaya gönüllü ve istekli olarak 1352 kişi katılmıştır. Veri toplama aracı olarak, araştırmacılar tarafından geliştirilen likert türünde 7 faktörlü ve 58 maddeden oluşan bir ölçek kullanılmıştır. Araştırma kapsamında elde edilen veriler, SPSS 20.0 ve LISREL 9.2 paket programları kullanılarak çözümlenmiştir. Geliştirilen ölçeğin açımlayıcı faktör analizi sonucu faktör yüklerinin 402 ile 907 arasında değiştiğ $i$ görülmüştür. Kaiser-Meyer-Olkin değerinin ise .817 olduğu belirlenmiştir. Açıklanan toplam varyansin \%55.93 ve Cronbach's Alpha değerinin ise 907 olduğu bulunmuştur. Doğrulayıcı faktör analizi sonucunda $X^{2} / S d$ değerinin 1.93, RMSEA değerinin .04, NNFI değerinin .95, SRMR değerinin .07 ve AGFI değerinin .75 olduğu bulunmuştur. Araştırma sonuçlarma göre geçerliği ve güvenirliği sağlanan bir ölçek geliştirilmiş ve paydaş görüşlerinin (öğretmen adayları, öğretmenler, öğretim üyeleri) kalite standartlarına "oldukça önemli" düzeyinde katılım sağladıkları belirlenmiştir.

Anahtar Kelimeler: Fen bilgisi öğretmen yetiştirme programı, yönetim ve idari hizmetler, kalite standartları, ölçek geliştirme 


\section{Introduction}

A country's competitiveness and development efforts are determined by the qualified manpower it has trained. Reaching qualified manpower is possible with a good higher education (Adigüzel, 2008). The quality of education and training services has an important place in the development, growth, development and creation of qualified manpower of a country (Özden, 2000). Countries that have developed and proven themselves in the field of technology in this regard make large investments in education systems every year (Bakioğlu and Ülker, 2015). Because the most important and last step that individuals have taken before starting their professional life is higher education (Ayaydın, 2010; Kalayc1, 2008).

The structure, working style, quality indicators and competitiveness of higher education institutions are changing with each passing day (Güleş, 2013). Thanks to the internet, people can examine the whole world and be aware of all developments. This situation also affects the universities and higher education programs that families will choose for their children. Families are now comparing universities and prefer the ones that have proven themselves in terms of quality, standards and competences (Yllmaz, 2018). An important component of universities that have proven themselves with respect to their competence is education faculties and teacher training units. Teachers are groups that direct society and play an active role in the creation of qualified manpower, especially from the onset of childhood (Eacute and Esteve, 2000). For this reason, teacher training programs in higher education institutions should have a structure that can keep up with the needs of the age and operate at certain standards (Yanpar-Yelken, Çelikkaleli, and Çapri, 2007). Some new concepts emerge in line with these purposes in higher education. These are; quality, accreditation, standards, evidence and indicators (European Network of Quality Assurance Agencies [ENQA], 2008).

Among these concepts, only the concepts of quality and standard have been mentioned in accordance with the research subject. The concept of quality has many equivalents in the literature. According to the Turkish Language Institution (TDK, 2021a), quality is defined as "Qualification", while the concept of Qualification is defined as "the feature, qualification, 
and arbitrariness that indicates how something is and that separates it from other things." As it can be understood from the related definition, it is not possible to use the concept of quality in all scientific fields with a single definition. Therefore, it is necessary to handle the concept of quality in education separately. Quality education can be defined as follows it is the coexistence of many features such as perfection (free from mistakes), functionality (ability to address many disciplines), economy (gain from time, space and workforce) and keeping up with the era (Delfino and Persico, 2007; Saç, 2016).

It goes without saying that, it is inevitable for a quality education to have certain standards (Bakioğlu and Ülker, 2015). Especially having standards that are valid all over the world and assuring certain competencies will seriously affect the quality of education. The notion of "standard" according to TDK (2021b) is "the rule put in order to determine a product, a working method, the amount to be produced, the amount of money in the budget" in an enterprise. The equivalent of this concept in educational sciences can be defined as all kinds of indicators, concrete outputs and general expressions given to the services provided in order to determine the competencies of an educational process and to examine its responsiveness to the needs (Hesapçıŏlu, 2003). The first large-scale study on determining quality standards in teacher training programs in our country was carried out in 1998. Council of Higher Education (CoHE/YÖK) and the World Bank (WB) conducted this project entitled "Teacher Education Standards and Accreditation in Turkey" and a number of accreditation and standard criteria were determined then (YÖK, 1998, 1999a, 1999b).

As for quality standards in higher education studies in Turkey they seem to have accelerated after 1998. First of all, quality and accreditation procedures were performed in engineering programs and with the achievement of satisfactory results, these practices were also used in teacher training programs (Turan, 2013). Science education and science teacher training programs have a special place among teacher training programs in our country. Because science education is an important branch of science that contains many different disciplines and prepares the individual for life. Understanding and applying the innovations and technological developments required by the age is basically possible with science edu- 
cation. For this reason, determining the quality standards of science teacher training programs would be an appropriate attempt. Many studies have been conducted on science teacher training programs. These studies take the form of various shape like; comparison studies (Ersoy, 2006; Kocakaya, 2015; Korkmaz, 2013), research on professional competence (Baştürk, 2008; Seferoğlu, 2004), studies on program development (Demirbaş and Yağbasan, 2005; Özyurt, 2014; Tukur, 2016), teacher problems (Sançmıs, 2014), research done for determination of science teacher competencies (MEB, 2002, 2006, 2008) and the ones concentrating upon teacher training policies (Çeliker, 2015; Meraler, 2011). However, it has been observed that there are not enough number of studies regarding quality standards. Therefore, in the study, "Determination of Quality Standards for Management and Administrative Services in Science Teacher Training Programs" was aimed. The following sub-goals are included in the research:

1. Development of a valid and reliable quality standard scale for management and administrative services,

2. Implementation of the developed scale and determination of stakeholder opinions.

\section{Method}

In this study, survey method, which is one of the quantitative research methods, was preferred. The survey method is a model that provides indepth information about an event, fact or situation and aims to describe the situation without intervening in the process (Delice, 2015; Fraenkel and Wallen, 2003). In the literature, it is seen that the survey method is frequently preferred in determining the quality standards in teacher training programs and performing scale development practices (Erişen, 2001; Güleş, 2013; Turan, 2013; Yılmaz, 2018).

\section{The Study Group}

The study group of the research was determined by two different sampling methods. These sampling methods are criteria and appropriate sampling. The reason why these sampling methods are preferred is that they 
provide researchers with convenience and usefulness in terms of time, effort and cost (Büyüköztürk, Kılıç Çakmak, Akgün, Karadeniz, and Demirel, 2016). The research has two working groups. Initially, 65 science faculty members, 128 science teachers and 217 prospective science teachers participated in the pilot study. In the second and final application, 206 science faculty members, 501 science teachers and 645 prospective science teachers participated.

\section{Ethical Statement and Compliance with Rules}

During the development of the quantitative data collection tool used in the research, the necessary permissions were obtained from the rightful authors for the scales used, and references were made within the scientific framework. In addition, the participants were informed and necessary permissions were obtained through the informed consent forms. The entire research process was conducted within the framework of ethical rules.

\section{Development Process of Data Collection Tool and Data Collection}

In the research, "Quality Standards Scale for Management and Administrative Services in Science Teacher Training Programs" was used as the data collection tool. These sub-steps were followed in the development process of the scale (Baş, 2008; Karasar, 2006; McMillan and Schumacher, 2006):

- Establishing a conceptual infrastructure,

- Creating an item pool,

- Getting expert opinion,

- Pilot implementation and analysis,

- Making validity and reliability applications,

- Taking expert opinion and finalizing the scale.

Research data were collected over a period of approximately 6 months within the scope of the doctoral thesis study. The results of the data collection tool regarding validity, reliability and application results are explained in detail in the findings and discussion section. 


\section{Data Analysis}

Research data were analyzed in two stages. First, exploratory and confirmatory factor analysis was conducted during the scale development phase. These analyzes were analyzed with SPSS 20.0 and LISREL 9.2 package programs. In the second stage, the data collected with the help of the developed scale were subjected to descriptive and inferential statistics. Later, because the application data did not show normal distribution, the analyzes were completed using non-parametric tests (Kruskal Wallis and Mann Whitney U).

\section{Findings}

In the first stage of the research, a scale development application with validity and reliability was carried out. For this purpose, exploratory and confirmatory factor analyses were performed, respectively. Table 1 presents $\mathrm{KMO}$ and Bartlett test results for scale items.

Table 1. KMO and Bartlett test result

\begin{tabular}{lll}
\hline KMO Coefficient & & .817 \\
\hline \multirow{2}{*}{ Bartlett Test } & Chi-square value & 14037,129 \\
& Df & 1653 \\
& $\mathrm{p}(\mathrm{p}<.05)$ & .000 \\
\hline
\end{tabular}

When Table 1 is examined, it is seen that the KMO value is .817 and the Bartlett Test value is at the level of $p<.05(p=.000)$. These results indicate that the items of the scale can be factored and the sample size is sufficient. Table 2 shows the eigenvalue and variance rates of the scale.

When Table 2 is examined, it is seen that there are 11 factors with eigenvalues of 1 and above. However, while determining the factor structure, it is frequently emphasized in the literature to decide together with the scree plot. The scree plot graph is presented in Figure 1. 
Table 2. Eigenvalue and variance rates

\begin{tabular}{cccc}
\hline Factor & Eigenvalue & Variance (\%) & Cumulative (\%) \\
\hline 1 & 10,014 & 17,265 & 17,265 \\
2 & 5,568 & 9,599 & 26,865 \\
3 & 4,706 & 8,114 & 34,978 \\
4 & 3,863 & 6,661 & 41,639 \\
5 & 3,589 & 6,187 & 47,826 \\
6 & 2,462 & 4,245 & 52,072 \\
7 & 2,241 & 3,863 & 55,935 \\
8 & 1,729 & & \\
9 & 1,474 & & \\
10 & 1,293 & & \\
11 & 1,278 & & \\
\hline
\end{tabular}

When Figure 1 is examined, it is seen that the breaking point has a 7-factor structure. When both the eigenvalue table and the scree plot results are analyzed comparatively, it can be stated that it would be appropriate for the current scale to have a 7-factor structure. In Table 3, item factor loads and common variance results are presented. In studies on scale development in the field of educational sciences, the part that researchers spend the most time is usually the part where the number of factors is determined (Yilmaz and Aydin, 2017).

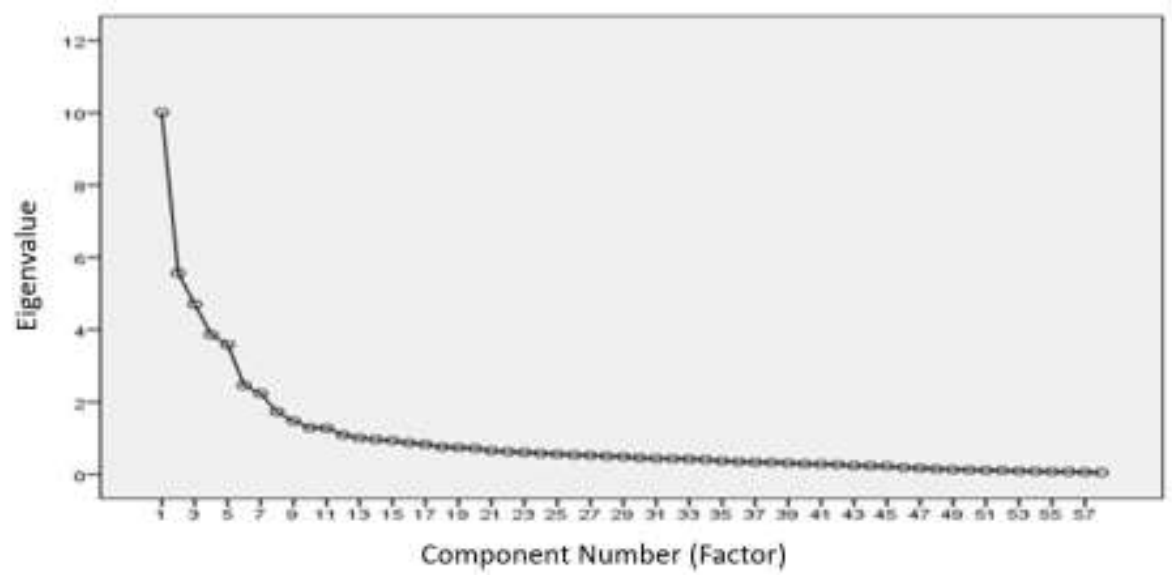

Figure 1. Scree plot graph

It is of great importance to determine the factors whose eigenvalue results are determined by the number of factors and whose eigenvalues are 
greater than 1 (Büyüköztürk, 2010). In the relevant literature, being concerned about increasing the quality of the scale and keeping the standards high, it is stated that choosing the eigenvalue ratio of 2 and above significantly affects the quality of the scale (Tabachnick and Fidell, 2007). For this reason, while determining the factor in the scale in question, factors of 2 and above were taken into account.

Table 3. Item factor loads and common variance results

\begin{tabular}{|c|c|c|c|}
\hline Factor & Item No & Factor Load & Total Variance \\
\hline \multirow{12}{*}{ Factor 1} & S1 & .768 & \multirow{12}{*}{17.265} \\
\hline & S2 & .722 & \\
\hline & S4 & .706 & \\
\hline & S5 & .690 & \\
\hline & S6 & .690 & \\
\hline & S3 & .678 & \\
\hline & S8 & .672 & \\
\hline & S10 & .666 & \\
\hline & S7 & .655 & \\
\hline & S9 & .625 & \\
\hline & S11 & .618 & \\
\hline & $\mathrm{S} 12$ & .504 & \\
\hline \multirow{11}{*}{ Factor 2} & S11 & .862 & \multirow{11}{*}{9.599} \\
\hline & S7 & .858 & \\
\hline & S2 & .829 & \\
\hline & S8 & .803 & \\
\hline & S9 & .706 & \\
\hline & S1 & .544 & \\
\hline & S3 & .460 & \\
\hline & S4 & .450 & \\
\hline & S5 & .445 & \\
\hline & S10 & .420 & \\
\hline & S6 & .402 & \\
\hline \multirow{11}{*}{ Factor 3} & S2 & .810 & \multirow{11}{*}{8.114} \\
\hline & S10 & .768 & \\
\hline & S11 & .753 & \\
\hline & S3 & .722 & \\
\hline & S1 & .636 & \\
\hline & S6 & .572 & \\
\hline & S4 & .527 & \\
\hline & S5 & .499 & \\
\hline & S7 & .484 & \\
\hline & S9 & .425 & \\
\hline & S8 & .422 & \\
\hline
\end{tabular}




\begin{tabular}{|c|c|c|c|}
\hline \multirow{7}{*}{ Factor 4} & S7 & .771 & \multirow{7}{*}{6.661} \\
\hline & $\mathrm{S} 2$ & .691 & \\
\hline & S5 & .667 & \\
\hline & S3 & .654 & \\
\hline & $\mathrm{S} 4$ & .645 & \\
\hline & S6 & .630 & \\
\hline & $\mathrm{S} 1$ & .528 & \\
\hline \multirow{7}{*}{ Factor 5} & S2 & .819 & \multirow{7}{*}{6.187} \\
\hline & S1 & .776 & \\
\hline & S3 & .761 & \\
\hline & S6 & .750 & \\
\hline & S5 & .731 & \\
\hline & $\mathrm{S} 4$ & .643 & \\
\hline & S7 & .616 & \\
\hline \multirow{5}{*}{ Factor 6} & S1 & $\begin{array}{l}.907 \\
\end{array}$ & \multirow{5}{*}{4.245} \\
\hline & $\mathrm{S} 4$ & .890 & \\
\hline & S2 & .876 & \\
\hline & S5 & .875 & \\
\hline & $\mathrm{S} 3$ & .754 & \\
\hline \multirow{5}{*}{ Factor 7} & S2 & .874 & \multirow{5}{*}{3.863} \\
\hline & S5 & .836 & \\
\hline & S4 & .780 & \\
\hline & S3 & .595 & \\
\hline & S1 & .554 & \\
\hline
\end{tabular}

In Table 3, item factor loads varied between .504 and .768 for the first factor, between .402 and .862 for the second factor, between .422 and .810 for the third factor, and between .528 and .771 for the fourth factor, for the fifth factor between .616 and .819 , for the sixth factor between .754 and .907 , and for the seventh factor between .554 and .874 values. In Table 4 , within the scope of the reliability analysis, the comparison of the averages of the upper group of $27 \%$ of the subgroups, the Cronbach's Alpha values at the item and dimension level, and the item total correlation results are presented. 
Table 4. Reliability analysis results

\begin{tabular}{|c|c|c|c|c|c|}
\hline \multirow[b]{2}{*}{ Factor } & \multirow[b]{2}{*}{ Item No } & \multirow{2}{*}{$\begin{array}{l}\text { t-value of Sub/Up- } \\
\text { pergroup mean dif- } \\
\text { ference }\end{array}$} & \multirow{2}{*}{$\begin{array}{l}\text { Item-Total } \\
\text { Correlations }\end{array}$} & \multicolumn{2}{|c|}{ Cronbach's Alpha } \\
\hline & & & & If Item Deleted & Factor \\
\hline \multirow{12}{*}{ 节 } & S1 & 12.741 & .572 & .887 & \multirow{12}{*}{.901} \\
\hline & S2 & 8.148 & .408 & .892 & \\
\hline & S3 & 10.027 & .486 & .892 & \\
\hline & S4 & 14.309 & .583 & .888 & \\
\hline & S5 & 9.975 & .456 & .891 & \\
\hline & S6 & 10.187 & .492 & .891 & \\
\hline & S7 & 8.258 & .379 & .894 & \\
\hline & S8 & 7.030 & .375 & .894 & \\
\hline & S9 & 9.853 & .461 & .895 & \\
\hline & S10 & 12.130 & .559 & .891 & \\
\hline & S11 & 9.191 & .430 & .895 & \\
\hline & S12 & 7.237 & .370 & .899 & \\
\hline \multirow{11}{*}{ 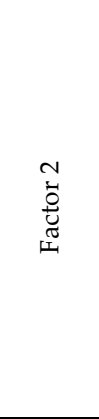 } & S1 & 11.727 & .539 & .845 & \multirow{11}{*}{.868} \\
\hline & S2 & 4.595 & .214 & .848 & \\
\hline & S3 & 3.749 & .209 & .863 & \\
\hline & S4 & 4.960 & .266 & .861 & \\
\hline & S5 & 11.126 & .480 & .857 & \\
\hline & S6 & 11.064 & .515 & .850 & \\
\hline & S7 & 8.825 & .400 & .859 & \\
\hline & S8 & 5.307 & .307 & .865 & \\
\hline & S9 & 9.196 & .462 & .864 & \\
\hline & S10 & 4.275 & .236 & .859 & \\
\hline & S11 & 5.374 & .238 & .854 & \\
\hline \multirow{11}{*}{ 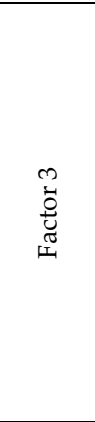 } & S1 & 2,770 & .126 & .849 & \multirow{11}{*}{.855} \\
\hline & S2 & 4.715 & 281 & .829 & \\
\hline & S3 & 6.323 & 366 & .851 & \\
\hline & S4 & .779 & .036 & .855 & \\
\hline & S5 & 2.795 & .170 & .854 & \\
\hline & S6 & .445 & .042 & .857 & \\
\hline & S7 & 4.836 & .290 & .826 & \\
\hline & S8 & 5.208 & 301 & .830 & \\
\hline & S9 & 4.628 & .237 & .840 & \\
\hline & S10 & 6.180 & .343 & .852 & \\
\hline & S11 & 4.474 & .275 & .825 & \\
\hline \multirow{7}{*}{ 节 } & S1 & 11.825 & .499 & .837 & \multirow{7}{*}{.849} \\
\hline & S2 & 7.640 & .383 & .826 & \\
\hline & S3 & 6.902 & .338 & .832 & \\
\hline & S4 & 9.505 & .430 & .830 & \\
\hline & S5 & 10.809 & .543 & .821 & \\
\hline & S6 & 10.804 & .494 & .831 & \\
\hline & S7 & 10.717 & .477 & .818 & \\
\hline
\end{tabular}




\begin{tabular}{|c|c|c|c|c|c|}
\hline \multirow{7}{*}{$\begin{array}{l}10 \\
\tilde{0} \\
0 \\
\tilde{0} \\
\tilde{T}\end{array}$} & S1 & 7.213 & .391 & .845 & \multirow{7}{*}{.872} \\
\hline & $\mathrm{S} 2$ & 5.107 & .269 & .844 & \\
\hline & S3 & 7.513 & .403 & .844 & \\
\hline & S4 & 4.291 & .251 & .869 & \\
\hline & S5 & 6.542 & .342 & .851 & \\
\hline & S6 & 5.911 & .282 & .854 & \\
\hline & S7 & 6.989 & .350 & .865 & \\
\hline \multirow{5}{*}{ 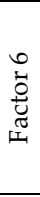 } & S1 & 8.185 & .382 & .905 & \multirow{5}{*}{.933} \\
\hline & S2 & 6.743 & .337 & .909 & \\
\hline & S3 & 5.399 & .275 & .948 & \\
\hline & S4 & 7.084 & .340 & .912 & \\
\hline & S5 & 7.219 & .350 & .912 & \\
\hline \multirow{5}{*}{ 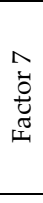 } & S1 & 4.760 & .222 & .855 & \multirow{5}{*}{.849} \\
\hline & $\mathrm{S} 2$ & 9.161 & .403 & .771 & \\
\hline & S3 & 5.279 & .254 & .846 & \\
\hline & S4 & 7.721 & .363 & .814 & \\
\hline & S5 & 9.340 & .403 & .790 & \\
\hline & & & \multicolumn{2}{|c|}{ Total Cronbach's Alpha } & .907 \\
\hline
\end{tabular}

It is significant at the $p<0.01$ level.

When Table 4 is examined, it is seen that the reliability levels of all scale items and all factors are within appropriate ranges. In addition, the general Cronbach's Alpha value for the whole scale was found to be .907. It can be said that the item total correlation values are .20 and above, except for a few items, and the items have a sufficient level of correlation. After the applications for the exploratory factor analysis, the results of the confirmatory factor analysis were given. There is the confirmatory factor analysis path diagram in Figure 2 and the index values of the goodness of fit in Table 5. 


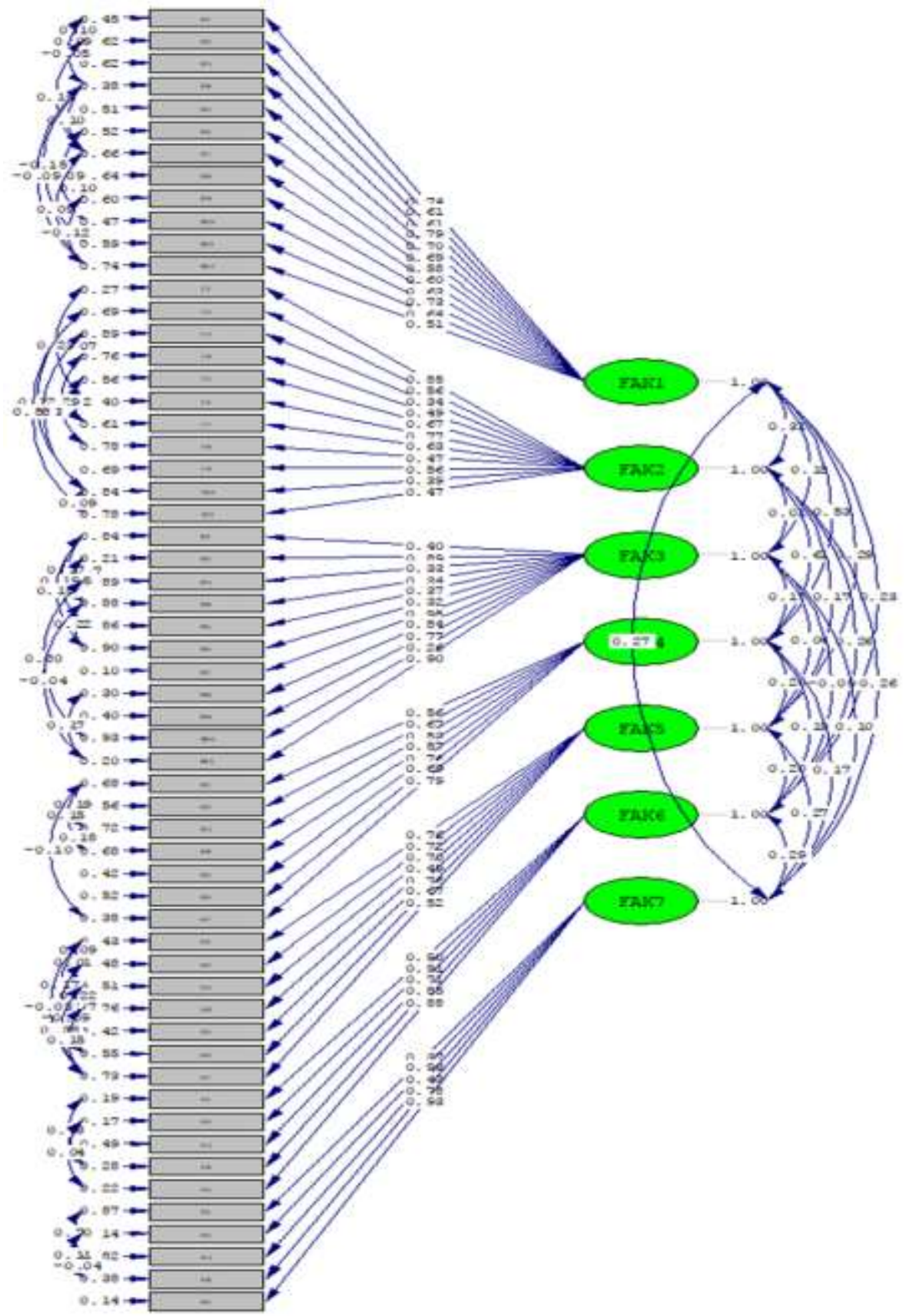

Figure 2. Confirmatory factor analysis path diagram 
Table 5. Goodness of fit index values

\begin{tabular}{ccc}
\hline Fit Indices & Values & Availability Status \\
\hline$X^{2}$ & 2961.06 & The appropriate value range \\
Df & 1527 & The appropriate value range \\
$X^{2} / D f$ & 1.93 & Perfect fit \\
$P$ & .052 & Perfect fit \\
RMSEA & .04 & Good/Acceptable fit \\
NFI & .90 & Good/Acceptable fit \\
NNFI & .95 & Perfect fit \\
CFI & .95 & Perfect fit \\
RMR & .08 & Good/Acceptable fit \\
SRMR & .07 & Good/Acceptable fit \\
AGFI & .75 & Low fit \\
GFI & .78 & Low fit \\
CN & 190.97 & Good/Acceptable fit \\
\hline
\end{tabular}

When Figure 2 and Table 5 are examined, it is found that $X^{2}$ value is 2961.06, Df 1527, X²/Df value is 1.93, p significance value is .052, RMSEA value is .04, NFI value is .90, NNFI value is .95, CFI value is .95, RMR value is .08. The SRMR value was found to be .07 , the AGFI value to be .75 , the GFI value to be .78 and the $\mathrm{CN}$ value to be 190.97 . When the values of goodness of fit are compared with the criteria in the literature, it is stated that this value is 5 and below is acceptable, 3 and below is at the level of good fit, and a value of 2 and below indicates perfect fit (Calvini, Fini and Ranieri, 2008). When the significance level and the RMSEA index value are controlled, the $p$ significance value is expected to be $p>.05$ (Kline, 1994). However, this value is often significant at .05 level $p<.05$. This is a problem arising from the fact that the scale items prepared in likert type are assumed as continuous data (Turan, 2013). When other fit indices were examined, it was determined that they were generally at a good/acceptable or perfect fit level. In the second stage of the research, the developed scale was applied. The research results were evaluated on general factors only. 
Table 6. Participant views on the scale sub-factors

\begin{tabular}{|c|c|c|c|c|c|c|c|}
\hline Standards & 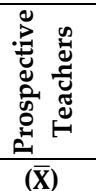 & 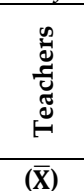 & 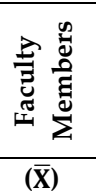 & $\mathrm{X}^{2}$ & Df & p & 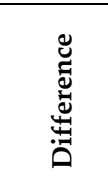 \\
\hline $\begin{array}{l}\text { Standards for Management } \\
\text { and Organization }\end{array}$ & 4.142 & 4.186 & 4.112 & 21.76 & 2 & .000 & $2>1,2>3$ \\
\hline $\begin{array}{l}\text { Standards for Administrative, } \\
\text { Social and Security Services }\end{array}$ & 3.990 & 4.133 & 3.925 & 7.47 & 2 & .024 & $2>1$ \\
\hline $\begin{array}{l}\text { Standards for Guidance Ser- } \\
\text { vices }\end{array}$ & 4.022 & 4.124 & 3.931 & 2.87 & 2 & .237 & - \\
\hline $\begin{array}{l}\text { Standards for Human Re- } \\
\text { sources Management }\end{array}$ & 4.074 & 4.115 & 4.008 & 5.04 & 2 & .080 & - \\
\hline Standards for the Library, & & & & & & & \\
\hline $\begin{array}{l}\text { Technology Center and Facili- } \\
\text { ties }\end{array}$ & 4.064 & 4.138 & 4.022 & 3.17 & 2 & .204 & - \\
\hline $\begin{array}{l}\text { Accounting and Finance } \\
\text { Standards }\end{array}$ & 4.122 & 4.258 & 4.038 & 14.49 & 2 & .001 & $2>1,2>3$ \\
\hline $\begin{array}{l}\text { Standards to Be Found in Fac- } \\
\text { ulty Management }\end{array}$ & 4.118 & 4.113 & 4.040 & 3.20 & 2 & .202 & - \\
\hline Total Mean & 4.070 & 4.149 & 4.031 & & & & \\
\hline
\end{tabular}

Prospective Teachers: 1, Teachers: 2, Faculty Members: 3

As a result of the scale application, it is seen that teachers have the highest average and faculty members have the lowest average. In addition, it is seen that there is a significant difference in management and organization, administrative, social and security services, accounting and financing categories and no significant difference in other factors. These results show that all participants have a significant level of participation in the scale items.

\section{Discussion, Conclusion and Suggestions}

This study, in which a scale for "Determination of Quality Standards for Management and Administrative Services in Science Teacher Training Programs" was developed and applied, was examined in two stages. First, a scale that is thought to serve the purpose was developed. During the development of the scale, a conceptual infrastructure was first established in light of the relevant literature and an item pool was prepared. Conceptual infrastructure and pool of items while creating the "Quality Standards, 
Bologna Process, the European Qualifications Framework, Turkey Higher Education Qualifications Framework, General and Specific Qualifications Towards Teaching Profession, Standards and Accreditation studies conducted by the Ministry of Education and Council of Higher Education" were considered and made in this field trials and item structures were examined (Yilmaz, 2018, p. 89). Expert opinion should be obtained after creating the item pool (Erkuş, 2012; Turan, 2013).

After taking the expert opinion, the first application of the scale was performed and the results obtained were interpreted. Accordingly, when Table 1 was examined, it was determined that the KMO value was .817. In studies conducted in the field of social sciences, it is reported that this value's being .50 and above is sufficient (McMillan and Schumacher, 2006; Özdamar, 2016). This situation is expressed similarly in many studies (Alakurt and Keser, 2015; Aydemir, Koçoğlu and Karalı, 2015; Bozdağ, Uğurel and Güzel, 2014; Kaban, 2013). At the same time, it was determined that the Bartlett test result was significant. Significance of both KMO value and Bartlett test result is the first criterion that should be paid attention to (Fraenkel \& Wallen, 2003; Tavşancıl, 2006). These results show that the sample of the application is sufficient and the questions from the item pool can be grouped (Özdamar, 2002).

When Table 2 is examined, the results of the eigenvalue and variance ratios are seen. In scale development practices, the eigenvalue of each factor is expected to be 1 and above (Erkus, 2012). The higher the eigenvalue ratio is determined, the less error tolerant the scale will become and a more qualified scale structure will be developed (Kline, 1994; Lawshe, 1975). Accordingly, it is seen that the developed scale consists of 11 factors with an eigenvalue of 1 and above. In addition to the eigenvalue situation, another point that should be considered is the variance ratio explained. In single factor structures, this ratio is desired to be $30 \%$ and above. For structures with more than one factor, the variance ratio should be $40 \%$ and above (Büyüköztürk, 2010; Can, 2016). As a matter of fact, this situation was found at similar rates in scale development studies in the literature (Erişen, 2001; Güleş, 2013; Kaban, 2013). When determining the factor structure of the scale, only eigenvalue and variance ratios are not accepted as criteria. In addition to these results, it is recommended to examine the results of the scree plot and to make factorization studies as a result of 
comparing these two results (George and Mallery, 2010). When the scree plot graph in Figure 1 is examined, it is seen that the breaking point of the scale starts to lose its slope after 7 factors. When this situation is compared with the eigenvalue table, it is seen that the eigenvalue ratio started to fall below 2 after the 7th factor. Hence, as a result of evaluating both tables together, it is thought that it would be appropriate to accept a scale structure with 7 factors and a variance ratio of $55.93 \%$. Factors named after the scale structure were determined. To that end, studies on quality standards in the field of teacher training (Erişen, 2001; Güleş, 2013; Kaban, 2013; Turan, 2013; Y1lmaz, 2018) were examined and the factors were named. Here, factors such as "Management and Organization, Administrative, Social and Security Services, Guidance Services, Human Resources Management, Library, Technology Center and Facilities, Accounting and Finance, Faculty Management" are named.

Several different criteria were taken into account in the process of eliminating the scale items and deciding on the final items. First of all, attention was paid to have item factor loads of .30 and above. When statistics-based sources and graduate studies are examined, it is stated that it is theoretically acceptable to have this value as .30 and above, but it is more appropriate to select the item factor load value as .40 and above (Brown, 2006; DeVellis, 2012). For this reason, attention was paid to select those with a factor load of .40 and above in the study. In addition, item factors that do not have a difference of .10 and above, which are called binary values were also examined. Another criterion in item selection is the examination of correlation matrices. Here, it is recommended that there should not be a relationship of .90 and above yet there needs to be a relationship at a medium level .50 (Field, 2009). As a matter of fact, when the scale items are examined, it is seen that there are results in appropriate value ranges. Finally, for each scale item, $27 \%$ lower group upper group averages were compared and non-significant items were determined and removed gradually from the scale. When the item factor loads are examined, it is seen that the lowest item is .402 and the highest item is .907 .

When Table 4 is examined regarding the scale structure, it is seen that there are reliability analyses. Accordingly, it was determined that Cronbach's Alpha values were appropriate both at the item level and at the factor level. It is stated that it is acceptable for this value to be .60 and 
above in educational sciences and social sciences (Büyüköztürk, 2010; Kane, 2001). Again, it can be stated that the item total correlation values and the lower group upper group averages also have appropriate value ranges. It is possible to find similar results in many studies in the literature. While the lowest reliability factor of the scale was .849 , the factor with the highest reliability was determined as .933 . The overall reliability coefficient of the scale was found to be .907 .

After the reliability results of the scale were found sufficient and the factor structure was determined as suitable, the other application i.e, the confirmatory factor analysis phase was started. At this stage, the construct validity, convergent and divergent validity of the scale were examined. When Figure 2 and Table 5 are examined together, it can be said that item factor loadings, correlation values between factors and sub-items, and index values of goodness of fit are in appropriate and acceptable ranges. It was determined that the $\mathrm{X}^{2} / \mathrm{Df}$ value was 1.93 and the $p$ value was (.052). In the literature, it is stated that the acceptable ranges of this value are 5 and below, and if it is 2 and below, it has perfect fit (Şimşek, 2007; Tabachnick and Fidell, 2007). Again, RMSEA, RMR and SRMR values are said to be acceptable if they are .08 and below. NFI, NNFI, CFI, AGFI and GFI values other than these values are expected to be .90 and above (Çokluk, Şekercioğlu and Büyüköztürk, 2014). However, here AGFI and GFI values were found slightly lower than other indexes. It can be said that this value can be tolerated since the goodness of fit results are high due to the general structure of the scale and the construct validity model is accurate. Another result is the $\mathrm{CN}$ (Critical Number) value. This value is expected to be 100 and above. When all the goodness of fit index values are examined, it can be stated that the scale is within the appropriate value ranges.

When the convergent validity results are examined, it is seen that the scale items have significant correlations for each factor and the error coefficients are low. When the divergent validity results are examined, it is seen that for each factor, there is no significant correlation between the items in the other factors and the error coefficients are low. Accordingly, it can be said that the scale has both structural, convergent (between items) and divergent (between factors) validity. After a valid and reliable scale was developed, this scale was applied in the second stage. When Table 6 is examined, it is seen that there is a significant difference between the 
participants in only 3 factors, and there is no significant difference in the other 4 factors. In general, it is seen that the opinions of the participants are between 3.925 and 4.258 average values. This range indicates that all participants expressed their opinions at a very significant level and that participation rates were high. When the factors with significant differences are examined, it is seen that, in general, teachers have the highest attitude and faculty members have the lowest attitude. There can be many reasons for this situation. Teachers can show a more positive tendency in terms of their professional development, thanks to the related situations and improvement work. As the faculty members are in the academic dimension of this work, they can delve into the critical aspects since they conduct scientific research at deeper levels. This critical point of view can naturally lead to lower expectations from and opinions about standard items. The prospective teachers, on the other hand, have opinions ate a medium level. They are neither able to do research in the profession as much as teachers nor can they do research as in-depth as faculty members. Therefore, it can be seen as an expected result that prospective teachers have an intermediate view. As a result of this research, the following suggestions can be made;

- The study was conducted with prospective teachers, teachers and faculty members. By expanding the scope of the research, a more comprehensive study can be conducted that includes lawmakers, politicians, exosystemic bodies such as YÖK and MEB.

- On the basis of science education programs, the rate of implementation of quality standards in education faculties can be determined and controlled practically.

- In this study, only some standard dimensions of science teacher training programs were examined. By expanding the scope of the research, quality standards can be determined in other departments and other fields.

- In the research process, only the undergraduate dimension was considered. Research can be carried out in postgraduate, doctorate, other levels with competence and equivalence in art.

- The scale developed within the scope of the research is recommended to be used by faculties and units affiliated to the rectorate in studies on quality and accreditation. 


\section{References}

Adıgüzel, A. (2008). Eğitim fakültelerinde öğretmen eğitimi program standartlarının gerçekleşme düzeyi. Doktora Tezi, Anadolu Üniversitesi Eğitim Bilimleri Enstitüsü. Eskişehir.

Alakurt, T., and Keser, H. (2015). Bilgi paylaşma davranışları ölçeği: Ölçek geliştirme çalısması. Kastamonu Ĕ̆itim Dergisi, 24(3), 1033-1054.

Ayaydın, A. (2010). Görsel sanatlar eğitiminde standart kavramı. Kastamonu Ĕ̆itim Fakültesi Dergisi, 18(1), 159-172.

Aydemir, H., Koçoğlu, E., and Karalı, Y. (2015). Grasha-Reichmann ölçeğine göre öğretmen adaylarının öğrenme stillerinin değerlendirilmesi. Kastamonu Eğitim Dergisi, 24(4), 1881-1896.

Bakioğlu, A., and Ülker, N. (2015). Üniversitede akreditasyon. 1. Basım, Ankara: Nobel Akademi.

Baş, T. (2008). Anket nasıl hazırlanır uygulanır değerlendirilir? (5. Baskı). Ankara: Seçkin Yayın Dağıtım.

Baştürk, R. (2008). Fen ve teknoloji alanı öğretmen adaylarının kamu personeli seçme sinavı başarılarının yordanması. İlköğretim Online, 7(2), 323-332.

Bozdağ, S., Uğurel, I., and Güzel, E. (2014). Matematik öğretmen adaylarını ispat ve ispatlamaya yönelik tutumlarının belirlenmesi: Bir ölçek geliştirme çalısması. Kastamonu Ĕ̆itim Dergisi, 23(4), 1585-1600.

Brown, T. A. (2006). Confirmatory factor analysis: For applied research. New York: Guilford.

Büyüköztürk, Ş. (2010). Sosyal bilimler için veri analizi el kitabr: İstatistik, araștrma deseni SPSS uygulamalar ve yorum (11. Baskı). Ankara: Pegem Akademi.

Büyüköztürk, Ş., Kilıç Çakmak, E., Akgün, Ö. E., Karadeniz, Ş., and Demirel, F. (2016). Bilimsel araştırma yöntemleri. 20. Baskı, Ankara: Pegem Akademi.

Can, A. (2016). SPSS ile bilimsel araştrma sürecinde nicel veri analizi. (4.Baskı). Ankara: Pegem Akademi.

Calvini, A., Fini, A., and Ranieri M. (2008). Models and instruments for assessing digital competence at school. Journal of E-Learning and Knowledge Society, (4)3, 183-193.

Çeliker, G. (2015). Eğitim bilimleri ve öğretmen yetiştirme alan uzmanlarınn eğitimde program değerlendirme öz-yeterlik düzeylerinin incelenmesi. Yüksek Lisans Tezi, Eskişehir Osmangazi Üniversitesi Eğitim Bilimleri Enstitüsü. Eskişehir. 
Çokluk, O., Şekercioğlu, G., and Büyüköztürk, S. (2014). Sosyal bilimler için çok değişkenli istatistik: SPSS ve LISREL uygulamalar. Ankara: Pegem Akademi.

Delfino, M., and Persico, D. (2007). Online or face to face? Experimenting with different techniques in teacher training. Journal of Computer Assisted Learning, 23, 351-365.

Delice, A. (2015). Karma yöntem desen seçimi. Y. Dede and S. B. Demir (Eds.), Karma yöntem araştırmalan tasarımı ve yürütülmesi. 2. Baskı, Ankara: Anı Yayınalık.

Demirbaş, M., and Yağbasan, R. (2005). Türkiye'de etkili fen öğretimi için ilköğretim kurumlarına yönelik olarak gerçekleştirilen program geliştirme çalışmalarının analizi ve karşılaşılan problemlere yönelik çözüm önerileri. Gazi Üniversitesi Kirşehir Ĕ̈itim Fakültesi, (6)2, 53-67.

DeVellis, R. F. (2012). Scale development: Theory and applications. Thousand Oaks. SAGE.

Eacute, J., and Esteve, M. (2000). The transformation of the teachers' role at the end of the twentieth century: New challenges for the future. Educational Review, 52(2), 197-209.

Erişen, Y. (2001). Öğretmen yetiştirme programlarına ilişkin kalite standartlarının belirlenmesi ve fakültelerin standartlara uygunluğunun değerlendirilmesi. Doktora Tezi, Ankara Üniversitesi Ĕ̆itim Bilimleri Enstitüsü. Ankara.

Erkuş, A. (2012). Psikolojide ölçek ve ölçek geliştirme-I: Temel kavramlar ve işlemler (1. Baskı). Ankara: Pegem Akademi.

Ersoy, Y. (2006). TIMSS-R aynasından yansitmalar-I: Türkiye' de fen bilgisi öğretmenlerinin genel görünüşü. Türk Fen Eğitimi Dergisi, 3(1), 19-35.

European Network of Quality Assurance Agencies (ENQA) (2008). Quality procedures in the Eurupen higher education area and beyond: Second ENQA survey. Helsinki: ENQA.

Fraenkel, J. R., and Wallen, N. E. (2003). How to design and evaluate research in education, (5th Ed.). New York: McGraw-Hill.

Field, A. (2009). Discovering statistics using SPSS (Third Ed.). London: SAGE.

George, D., and Mallery, M. (2010). SPSS for windows step by step: A simple guide and reference. Boston: Pearson.

Güleş, F. (2013). Okul öncesi eğitimde fiziksel çevreye ilişkin kalite standartlarının belirlenmesi. Doktora Tezi, Selçuk Üniversitesi Sosyal Bilimler Enstitüsü. Konya.

Hesapçığlu, M. (2003). Ĕ̆itim kurumlarnnda kalite olgusu ve kalite güvence sistemleri. İstanbul: Marmara Üniversitesi Yayınları. 
Kaban, A. (2013). Uzaktan eğitim kalite standartlarının belirlenmesi ve Atatürk Üniversitesi uzaktan eğitim sisteminin incelenmesi. Doktora Tezi, Gazi Üniversitesi Ĕ̈itim Bilimleri Enstitüsü. Ankara.

Kalayc, N. (2008). Yüksekögretimde uygulanan toplam kalite yönetimi sürecinde gözardı edilen unsurlardan “Tky Merkezi” ve "Eğitim Programları”. Türk Ĕ̈itim Bilimleri Dergisi, Bahar, 6(2), 163-188.

Kane, M. T. (2001). Current concerns in validity theory. Journal of Educational Measurement, 38(4), 319-342.

Karasar, N. (2006). Bilimsel araştırma yöntemi (16. Baskı). Ankara: Nobel.

Kline, P. (1994). An easy guide to factor analysis. UKK Routledge:1990.

Kocakaya, P. (2015). Türkiye, Fransa ve İsviçre'de öğrenim gören fen alanları öğretmen adaylarının teknopedagojik yeterliklerinin yapısal eşitlik modeli ile incelenmesi. Doktora Tezi, Dicle Üniversitesi Fen Bilimleri Enstitüsü. Diyarbakır.

Korkmaz, H. (2013). Türkiye ve Amerika Birleşik Devletleri'nde kim fen öğretmenlerinin eğitimcisi olmaktadır? Bir karşılaştırma çalışması. Hacettepe Üniversitesi Ĕ̈itim Fakültesi Dergisi, Özel Sayı (1), 256-270.

Lawshe, C. H. (1975). A quantitative approach to content validity. Personnel Psychology, 28, 563-575.

McMillan, J. H., and Schumacher, S. (2006). Research in education: Evidence-based inquiry (sixth Ed.). Boston: Pearson.

Milli Eğitim Bakanlı̆̆ (MEB) (2002). Öğretmen yeterlilikleri. Öğretmen Yetiştirme ve Eğitimi Genel Müdürlüğü, Ankara: Millî Eğitim Basımevi.

MEB (2006). Ülkelerin öğretmen yetiştirme sistemleri. Ankara: MEB Yayınevi.

MEB (2008). Öğretmen yeterlilikleri: Öğretmenlik mesleği genel ve özel alan yeterlilikleri. Ankara: Devlet Kitapları Müdürlüğü.

Meraler, S. (2011). Eğitim fakültesi öğrencilerinin yükseköğretimde kaliteye ilişkin görüşlerinin belirlenmesi. Yüksek Lisans Tezi, Harran Üniversitesi Sosyal Bilimler Enstitüsü. Şanlıurfa.

Özdamar, K. (2002). Paket programlar ile istatistiksel veri analizi 1. Eskişehir: Kaan Kitapevi.

Özdamar, K. (2016). Eğitim, să̆ lık ve davranış bilimlerinde ölçek ve test geliştirme yapısal eşitlik modellemesi. Eskişehir: Nisan Kitabevi.

Özden, Y. (2000). Ĕ̆itimde yeni değerler. Ankara: Pegem Akademi. 
Özyurt, Y. (2014). Fen bilgisi öğretmenliği lisans programı dersleri ögrenme çktılarının fen ve teknoloji öğretmenliği özel alan yeterlikleri ile örtüşme düzeyi. Yüksek Lisans Tezi, Abant İzzet Baysal Üniversitesi Eğitim Bilimleri Enstitüsü. Bolu.

Saç, C. (2016). 2002-2014 yılları arasında öğretmen yetiştirme ve atama politikalarının değerlendirilmesi. Yüksek Lisans Tezi, Atatürk Üniversitesi Ĕ̆itim Bilimleri Enstitüsü. Erzurum.

Sançmış, F. (2014). Zorunlu yer değiştirmiş öğretmenlerin yaşadıkları sorunların belirlenmesi. Yüksek Lisans Tezi, Yeditepe Üniversitesi Sosyal Bilimler Enstitüsü. İstanbul.

Seferoğlu, S. S. (2004). Öğretmen adaylarının öğretmen yeterlilikleri açısından kendilerini değerlendirmeleri. Hacettepe Üniversitesi Eğitim Fakültesi Dergisi, 26, 131140.

Şimşek, Ö. F. (2007). Yapısal eşitlik modellemesine giriş: Temel ilkeler ve LISREL uygulamalan. Ankara: Ekinoks.

Tabachnick, B. G., and Fidell, L. S. (2007). Using multivariate statistics (5th Ed.). Boston: Allyn ve Bacon.

Tavşancıl, E. (2006). Tutumlarm ölçülmesi ve SPSS ile veri analizi (3. Baskı) Ankara: Nobel. Tukur, M. M. (2016). Fen bilgisi öğretmeni yetiştirme programlarından mezun olan yabanc uyruklu öğretmen adaylarının programlar hakkındaki tutumları. Yüksek Lisans Tezi, Frrat Üniversitesi Ĕgitim Bilimleri Enstitüsü. Elazığ.

Turan, E. Z. (2013). Din kültürü ve ahlak bilgisi öğretmen yetiştirme programlarına ilişkin kalite standartlarnnın belirlenmesi. Doktora Tezi, Necmettin Erbakan Üniversitesi Sosyal Bilimler Enstitüsü. Konya.

Türk Dil Kurumu [TDK] (2021a). "Kalite" ve "Nitelik" kavramı nedir? 15-02-2021 tarihinde https://sozluk.gov.tr/ adresinden erişilmiştir.

TDK (2021b). "Standart" kavram nedir? 18-02-2021 tarihinde https://sozluk.gov.tr/ adresinden erişilmiştir.

Yanpar-Yelken, T., Çelikkaleli, Ö., and Çapri, B. (2007). Eğitim fakültesi kalite standartlarının belirlenmesine yönelik öğretmen adayı görüşleri. Mersin Üniversitesi Eŏitim Fakültesi Dergisi, 3(2), 191-215.

Yllmaz, A., and Aydın, S. (2017). Quality standards for the content of the program and admission to the students in science education teacher training programs. International Teacher Education Conference, 168-169. Cambridge, USA. 
Yılmaz, A. (2018). Fen bilgisi öğretmen yetiştirme programlarında kalite standartlarının belirlenmesi: Ölçek geliştirme ve uygulama çalışması. Doktora tezi. Kastamonu Üniversitesi Fen Bilimleri Enstitüsü. Kastamonu.

Yüksek Öğretim Kurulu (YÖK). (1998). Öğretmen eğitiminde akreditasyon: Ingiltere ve ABD örnekleri. Ankara: YÖK.

YÖK (1999a). Eğitim fakültelerinde öğretmen yetiştirme programlarnn geliştirilmesine yön veren temel ilkeler. Ankara: YÖK.

YÖK (1999b). Türkiye'de öğretmen eğitiminde akreditasyon ve standartlar. YÖK/Dünya Bankası Milli Eğitimi Geliştirme Projesi Hizmet Öncesi Öğretmen Eğitimi. Ankara.

\section{Kaynakça Bilgisi / Citation Information}

Yilmaz, A. and Aydın S. (2021). Determination of quality standards for management and administrative services in science teacher training programs. OPUS-International Joutnal of Society Researches, 17(37), 4760-4783. DOI: 10.26466/opus. 893880 